\section{COVID-19 and return-to-work recommendations for people with chronic respiratory diseases}

Lauren Vogel examines Canada's preparation for a second wave of the coronavirus disease 2019 (COVID-19) pandemic. ${ }^{1}$ As restrictions ease, patients with chronic diseases are contacting physicians to inquire when they can return to work safely. Employers are posing similar questions. There is a consensus among many of the physicians responding to these questions: there are no definitive answers. Few formal recommendations for returning to work focus on people with chronic diseases.

In our experience with patients with lung disease, the decision to return to work is influenced by 2 factors: these patients may be at greater risk of acquiring COVID19 and of having more serious adverse outcomes if infected with severe acute respiratory syndrome coronavirus 2 (SARS-CoV-2), the virus that causes COVID-19. Data suggest a lower-than-expected prevalence of COVID-19 in those with asthma and chronic obstructive pulmonary disease (COPD). However, these individuals may yet be at greater risk of developing severe illness if they acquire COVID-19. ${ }^{2}$ It is also possible that SARS-CoV-2 infection in someone with asthma or COPD could trigger an asthma or COPD exacerbation and related complications. ${ }^{3}$ It is unclear whether diseases like pulmonary fibrosis, cystic fibrosis or cancer put patients at higher risk of infection. ${ }^{4}$ One meta-analysis found an elevated odds ratio for people with lung disease developing severe COVID-19. ${ }^{2}$ With a potential return to routine social practices in the fall, finding strategies to get patients safely back to work will be vital.
The pillars of preventing disease transmission in the workplace will undoubtedly rest on principles of masking, handwashing, physical distancing and staying home when ill. These measures are inexpensive and adaptable to most settings. Beyond this, return-to-work plans could stratify people by age, disease severity and occupation. As older age is linked to worse outcomes, young people might return sooner. ${ }^{2}$ Given the lack of evidence, disease-specific advice remains limited. The Canadian Thoracic Society recommends that patients with asthma work from home. ${ }^{5}$ If those with severe asthma cannot do so, they should remain off work until social distancing is not mandated. ${ }^{5}$ The society also recommends that patients with COPD stay home as much as possible. ${ }^{6}$ These proposals are based on expert opinion and past experience with influenza outbreaks. Moreover, workers in health care may be at increased risk of acquiring COVID-19, but people employed in industries like retail, hospitality and transport likely are, too. ${ }^{1,5}$ Studies assessing exposure risk in non-health care settings are needed.

Medical societies must use evolving data to make disease-specific recommendations for returning to work. The Canadian Thoracic Society is on the mark in using flexible statements that are updated regularly. As evidence builds, guidance may be more targeted. For example, patients might be stratified more precisely by pulmonary function test results.

Physicians are best positioned to provide personalized guidance to patients. Recognizing there is a paucity of good data, some uncertainty will be inevitable. However, more professional consensus will empower physicians to offer the most evidenceinformed advice and advocate for patients to receive needed accommodations. Until the pandemic wanes or a vaccine is available, physicians will share responsibility for deciding when and how people with chronic diseases should return to work.

\section{Max Deschner MD}

Resident physician, Department of Medicine, Western University, London, Ont.

\section{Grace Parraga PhD}

Professor, Department of Medicine, Western University, London, Ont.

\section{Cory Yamashita MD}

Physician, Department of Medicine, Division of Respirology, Western University, London, Ont.

- Cite as: CMAJ 2020 August 31; 192:E1021. doi: 10.1503/cmaj.76441

\section{References}

1. Vogel L. Is Canada ready for the second wave of COVID-19? CMAJ 2020;192:E664-5.

2. Yang J, Zheng Y, Gou X, et al. Prevalence of comorbidities and its effects in patients infected with SARS-CoV-2: a systematic review and metaanalysis. Int J Infect Dis 2020;94:91-5.

3. Abrams E, 't Jong Geert, Yang C. Paediatric asthma and COVID-19. Ottawa: Canadian Paediatric Society; 2020. Available: www.cps.ca/en/ documents/position/paediatric-asthma-and -covid-19 (accessed 2020 Aug. 12).

4. Halpin DMG, Faner R, Sibila O, et al. Do chronic respiratory diseases or their treatment affect the risk of SARS-CoV-2 infection? Lancet Respir Med 2020;8:436-8.

5. Licskai C, Yang CL, Ducharme FM, et al. Addressing therapeutic questions to help Canadian physicians optimize asthma management for their patients during the COVID-19 pandemic. Can J Resp Crit Care Sleep Med 2020;4:73-6.

6. Bhutani M, Hernandez P, Bourbeau J, et al. Addressing therapeutic questions to help Canadian health care professionals optimize COPD management for their patients during the COVID-19 pandemic. Can J Resp Crit Care Sleep Med 2020;4:77-80.

Competing interests: None declared. 